\title{
A new tool to follow the changes of geographic names on globes
}

\author{
Zoltán KURIS a , Klaudia RAPCSÁN ${ }^{\text {b }}$, Zsuzsanna UNGVÁRI ${ }^{\mathrm{c}}$, Mátyás GEDE ${ }^{\mathrm{d}, *}$ \\ ${ }^{a}$ ELTE Eötvös Loránd University, Faculty of Informatics, Institute of Cartography and Geoinformatics, Budapest, Hungary \\ ${ }^{b}$ Cartographer, Naviscon ZRt., klaudia.rapcsan@naviscon.hu \\ ${ }^{c}$ ELTE Eötvös Loránd University, Faculty of Informatics, Institute of Cartography and Geoinformatics, Budapest, Hungary, \\ ungvarizs@map.elte.hu \\ ${ }^{d}$ ELTE Ë̈tvös Loránd University, Faculty of Informatics, Institute of Cartography and Geoinformatics, Budapest, Hungary, \\ saman@map.elte.hu \\ * Corresponding author
}

Keywords: virtual globes, comparative search in geographic names

\begin{abstract}
The Virtual Globes Museum ${ }^{1}$ (VGM) is one of the largest project of the last 15 years at the Institute of Cartography and Geoinformatics. In this project, many publications appeared in journals and conferences, but the geographic names on the globes were less studied topics. Therefore, the new idea was to create a database and a searching application, where users can follow the changes of geographic names from the middle of $19^{\text {th }}$ century (when the first printed Hungarian globes were published) until nowadays.

Thirty globes was selected from VGM. The earliest one was made in 1840 and its diameter is $31.65 \mathrm{~cm}$. This one has already contain the new pursuits of Hungarian Language Reform. There are several globes from the second half of the $19^{\text {th }}$ century in VGM: these ones served in the geography education and spread in the primary and secondary schools. These globes names were translated to Hungarian by János Hunfalvy (the famous geographer) and Pál Gönczy (teacher and geographer, secretary of state of education), and their publishers were the Ernst Schotte \& Co. and Jan Felkl (and son) Co. These globes became outdated for the beginning of $20^{\text {th }}$ century. The modernized maps were introduced by the Hungarian Geographic Institute - a firm lead by the Kogutowicz family. Then the most globes published between the World Wars continued the Kogutowicz era. The website also contains the globes of Cartographia, the monopolistic civil cartographic company of Hungary during the socialism (from 1965 to 1990), which mirrors the recent forms of geographic names. The selected globe's diameters are vary: the smallest is 5.8 and the largest is $51 \mathrm{~cm}$.
\end{abstract}

The database and the website were the project of four students in cartography: the initial dataset was recorded in 2010 in spreadsheet tables by Virág Szabó). Few years later (in 2017), the first version of the website was created (by Arthur Beszkid), which contained only the sea names, and visualized them on a virtual globe. Klaudia Rapcsán introduced the names of capes and ocean's currents into the database, and finally Zoltán Kuris (2021) extended the website searching functions and added the river and lake names into the database.

The number of topopnyms is over 8000 recently: they are only the names of water system divided into five categories: names of seas, rivers, lakes, capes and ocean's currents. The goal was to create a searching application, which helps to follow the changes of names. Therefore, the folowing functions were added:

- Users can look up a name or a part of a name in the selected categories (for example „Atlanti” in sea category. "Atlanti” is the Hungarian form of Atlantic Ocean). As a result, they get the similar names in the database, and on which globe it can be found. The globe can be loaded into the right column, and visualize as a texture of a virtual globe (based on Cesium.js). Users can zoom in to the name's position.

-There are two dropdown lists, which help to compare the geographic names. In the first one, the users can select a globe, and a name category. Thereby, the list of names on the selected globe can be seen (For example: "Which cape names can be read on the $15.8 \mathrm{~cm}$ globe from Pál Gönczy?"). Additionally, the globe texture can be loaded on the virtual globe.

- In the second list, we can choose a name class, and a recent name form in the selected category. For instance, "Arabtenger" (Arab Sea) in sea category. In the result table, the users can see on which globe you can read this name. You can zoom in for the name's location and the texture also can be loaded.

Technical background: the website based on PHP and JavaScript. The visualization of globe texture and names happens using Cesium.js. The website is directly available on this link: http://terkeptar.elte.hu/vgm/vizrajz/ or from the VGM's site in the Related projects submenu.

In the last section, the authors shortly present some interesting facts learned about Hungarian geographic names: 
- It is possible to follow the changes of ortography (the conventions for writing) in geographic names. The first important reform in ortography was introduced in the 1950's and completed in $1965^{2}$. On the globes of Cartographia, these new rules were applied. The new conventions regulated among others the usage of hyphen (e.g. Földközi tenger / today's form Földközi-tenger [Mediterranean Sea] ).

- Changes of geographic knowledge in the $19^{\text {th }}$ century. There were still less known areas in the World in this time, therefore the smaller objects like rivers and lakes sometimes do not exist on the globe or are misplaced.

- Lake Parime is a legendary lake in Guayana can be found on eight globes made in the second half of $19^{\text {th }}$ century. The presence of this lake was refuted in the beginning of $19^{\text {th }}$ century, but unfortunately the globe makers could not get this information in time.

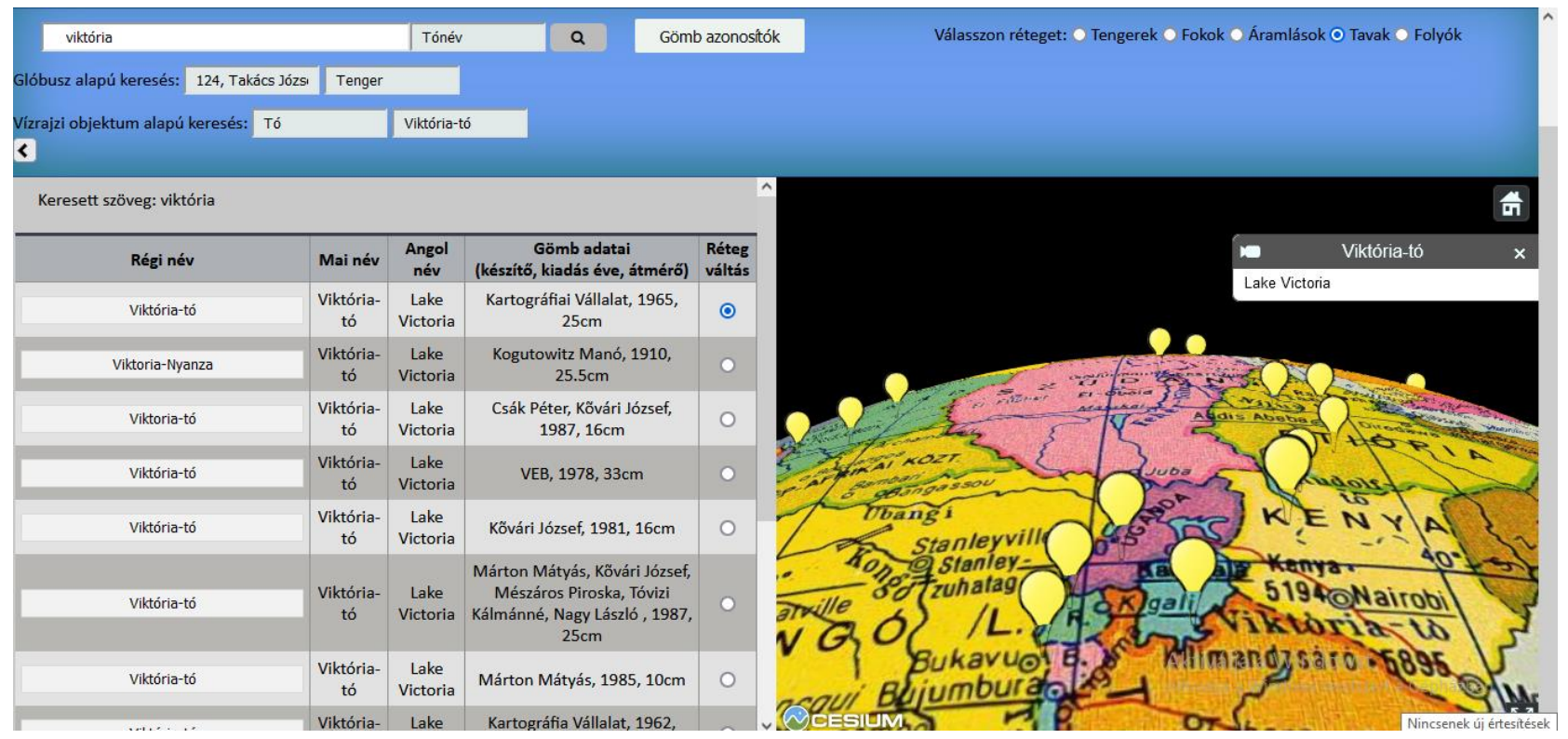

Figure 1. The user interface of the website

\section{References}

1: M Gede, Z Ungvári, L Zentai, 2013: Virtual Globes Museum 2.0 - Adding the Power of Community. In: Manfred F Buchroithner (ed.) Proceedings of the 26th International Cartographic Conference. Dresden

2: Magyar Nyelvi Bizottság Földrajzinév-Bizottság, 2003: A földrajzi nevek helyesírása. /Ortography of geographic names./ Akadémiai Kiadó. Budapest. 